\title{
Saline stress and potassium/calcium ratio in fertigated eggplant
}

\author{
Jefferson M. A. P. dos Santos ${ }^{1}$, Francisco de A. de Oliveira' ${ }^{1}$, José F. de Medeiros ${ }^{1}$, \\ Ana J. de O. Targino ${ }^{1}$, Luilson P. da Costa ${ }^{2} \&$ Sandy T. dos Santos ${ }^{1}$
}

${ }^{1}$ Universidade Federal Rural do Semi-Árido/Programa de Pós-Graduação em Manejo de Solo e Água. Mossoró, RN. E-mail: jeffersonmaps@gmail.com ORCID: 0000-0003-0531-2241; thikaoamigao@ufersa.edu.br (Corresponding author) - ORCID: 0000-0002-6895-7736; jfmedeir@ufersa.edu.br - ORCID: 0000-0003-1202-8783; ana_jacqueline2@hotmail.com - ORCID: 0000-0001-9072-1378; sandy_thomaz@hotmail.com - ORCID: 0000-0001-6487-555X

${ }^{2}$ Universidade Federal do Ceará/Programa de Pós-Graduação Fitotecnia. Fortaleza, CE. E-mail: luilson.costa@yahoo.com.br - ORCID: 0000-0002-6758-0180

\section{Key words:}

Solanum melongena L. cultivation of vegetables fertigation management salinity

\begin{abstract}
A B S T R A C T
In order to evaluate the effect of irrigation water salinity in interaction with different potassium and calcium ratios applied through fertigation in eggplant, an experiment was carried out at the Department of Environmental and Technological Sciences of the Federal Rural University of the Semi-Arid Region, in Mossoró, RN, Brazil. The experimental design was randomized blocks, in a $5 \times 4$ factorial scheme, with four replicates. The treatments were obtained by the combination between five ionic ratios of potassium and calcium (F1 $=4.2 / 1 ; \mathrm{F} 2=3.5 / 1 ; \mathrm{F} 3=2.8 / 1 ; \mathrm{F} 4=2.2 / 1 ; \mathrm{F} 5=1.8 / 1)$ and four levels of irrigation water salinity $\left(\mathrm{S}_{1}-0.5 ; \mathrm{S}_{2}-2.0 ; \mathrm{S}_{3}-3.5\right.$; and $\left.\mathrm{S}_{4}-5.0 \mathrm{dS} \mathrm{m}^{-1}\right)$. The following variables were evaluated: number of fruits per plant, fruit length, fruit diameter, fruit fresh weight and yield. Yield, fruit length, fruit fresh weight and number of fruits decreased with the increase of salinity in all the treatments. Salinity significantly affected fruit diameter, which increased only under fertigation with potassium-rich solutions.
\end{abstract}

\section{Palavras-chave:}

Solanum melongena L. cultivo de hortaliças manejo da fertigação salinidade

\section{Estresse salino e razão entre potássio e cálcio em berinjela fertigada}

\section{R E S U M O}

Com o objetivo de avaliar o efeito da salinidade da água de irrigação em interação com diferentes razões entre potássio e cálcio aplicados via fertigação em berinjela, instalou-se um experimento no Departamento de Ciências Ambientais e Tecnológicas da Universidade Federal Rural do Semi-Árido, em Mossoró, RN. O delineamento experimental utilizado foi em blocos casualizados, em esquema fatorial $5 \times 4$, com quatro repetições. Os tratamentos foram formados pela combinação entre cinco razões iônicas entre potássio e cálcio $\left(\mathrm{K}^{+} / \mathrm{Ca}^{2+}\right)(\mathrm{F} 1=4,2 / 1 ; \mathrm{F} 2=3,5 / 1 ; \mathrm{F} 3=2,8 / 1 ; \mathrm{F} 4=2,2 / 1 ; \mathrm{F} 5=1,8 / 1)$, com quatro níveis de salinidade na água de irrigação $\left(\mathrm{S}_{1}-0,5 ; \mathrm{S}_{2}-2,0 ; \mathrm{S}_{3}-3,5 ; \mathrm{e}_{4}-5,0 \mathrm{dS} \mathrm{m}^{-1}\right)$. Foram avaliadas as variáveis: número de frutos por planta, comprimento de frutos, diâmetro de fruto, massa fresca de frutos e produtividade. As variáveis produtividade, comprimento, massa fresca e número de frutos por planta apresentaram redução com o aumento da salinidade para todos os tratamentos. A salinidade afetou significativamente o diâmetro dos frutos, onde observou-se incremento apenas nas fertigações potássicas. 


\section{INTRODUCTION}

Eggplant (Solanum melongena L.), belonging to the Solanaceae family, is cultivated in different regions of the planet, occupying in 2012 an area of approximately 1.85 million hectares, with mean yield of $26 \mathrm{tha}^{-1}$ (FAO, 2015).

According to Ünlükara et al. (2010), eggplant is classified as moderately sensitive to salinity, with salinity threshold of $1.5 \mathrm{dS} \mathrm{m}^{-1}$ and relative yield loss of $4.4 \%$ per unit increase in salinity from this threshold on.

Reduction in fruit yield of eggplant under salt stress occurs due to physiological alterations, such as reduction in stomatal conductance and, at lower proportions, declines in the rates of transpiration, photosynthesis and internal $\mathrm{CO}_{2}$ concentration in the leaves (Bosco et al., 2009; Bsoul et al., 2016; Ghaemi \& Rafiee, 2016; Mahjoor et al., 2016).

Additionally, plants grown under salt stress, particularly in $\mathrm{NaCl}$-rich environment, may undergo nutritional imbalance due to the absorption of $\mathrm{Na}^{+}$and $\mathrm{Cl}^{-}$, which causes reduction in the concentration of cationic ions, especially $\mathrm{K}^{+}$and $\mathrm{Ca}^{2+}$, resulting in higher $\mathrm{Na}^{+} / \mathrm{K}^{+}$and $\mathrm{Na}^{+} / \mathrm{Ca}^{2+}$ ratios (Tammam et al., 2008).

The reduction in the concentration of these ions $\left(\mathrm{K}^{+}\right.$and $\mathrm{Ca}^{2+}$ ) in the plant can be harmful because of the functions performed by these elements; $\mathrm{K}^{+}$participates in important characteristics of production, such as uniform ripening and synthesis of photoassimilates, and $\mathrm{Ca}^{2+}$ has important structural functions, as a constituent of the cell wall and controlling water movement in the cells, being essential for cell division (Malavolta, 2006; Albino-Garduño et al., 2008).

As a way to minimize the effect of salinity on the competitive inhibition of the ions in the root zone, fertigation management, especially with respect to the $\mathrm{K}^{+} / \mathrm{Ca}^{2+}$ ratio, can be a strategy to reduce the negative effect of sodium, in particular, due to the increase in the applied quantities of these two ions in an attempt to decrease the absorption of the sodium ion by the plant (Rubio et al., 2009; Tzortzakis, 2010).

Given the above, the present study aimed to evaluate the effect of irrigation water salinity in interaction with different ratios of potassium and calcium applied through fertigation on eggplant.

\section{Material AND Methods}

The experiment was carried out from July 2016 to January 2017 , in the experimental sector of the Department of Environmental and Technological Sciences of the Federal Rural University of the Semi-Arid Region (UFERSA), in Mossoró,

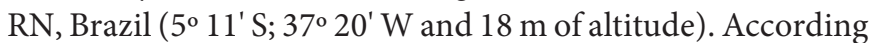
to Köppen's classification, the climate of the region is BSwh' (hot and dry), with very irregular precipitation and annual mean of $673.9 \mathrm{~mm}$ (Carmo Filho \& Oliveira, 1995).

During the experiment, climate data of temperature and relative air humidity were collected at the Automatic Meteorological Station of UFERSA, 2,200 $\mathrm{m}$ away from the experimental area. Minimum, maximum and mean values of temperature and relative air humidity were obtained (Figure 1).

The experimental design was randomized blocks, in $5 \times 4$ factorial scheme, with four replicates, resulting in
A.

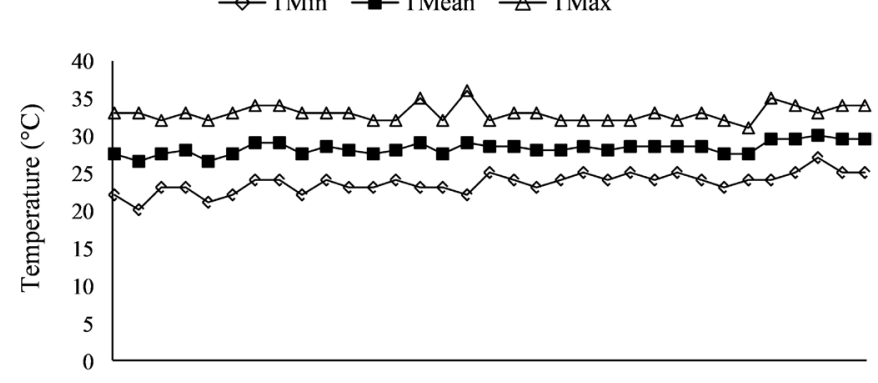

B.
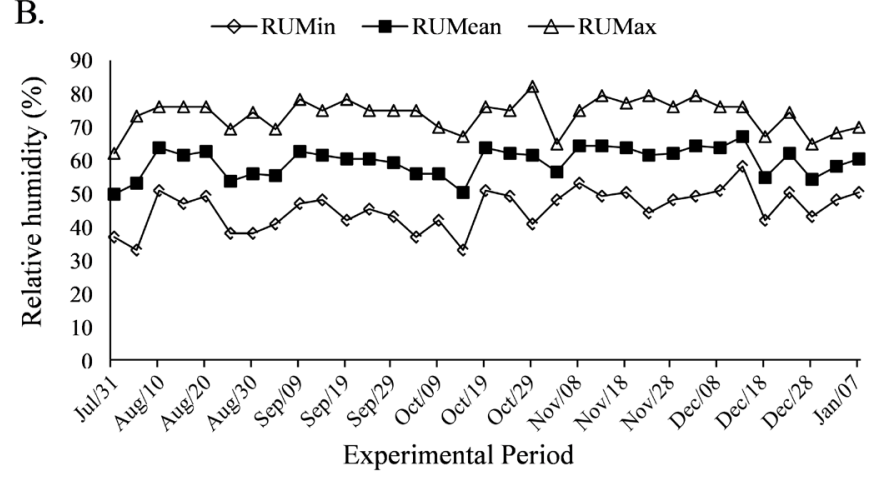

Figure 1. Climate data of temperature $(\mathrm{A})$ and relative air humidity (B) along the experimental period

80 experimental units, and each experimental unit was represented by one pot with capacity for $20 \mathrm{dm}^{3}$ of substrate, containing one plant.

Treatments resulted from the combination of five ionic ratios between potassium and calcium $\left(\mathrm{K}^{+} / \mathrm{Ca}^{2+}\right)$ in the fertigation $(\mathrm{F} 1=4.2 / 1 ; \mathrm{F} 2=3.5 / 1 ; \mathrm{F} 3=2.8 / 1 ; \mathrm{F} 4=2.2 / 1 ; \mathrm{F} 5$ $=1.8 / 1)$, with four levels of irrigation water salinity (S1-0.5; S2-2.0; S3-3.5 and S4-5.0 dS m-1). These levels were selected based on the electrical conductivity values found in the waters available for irrigation in the region where the experiment was conducted (Medeiros et al., 2003; Costa, 2008).

The quantities of macronutrients applied along the experiment for each fertigation treatment are presented in Table 1, in which F3 corresponds to the quantities of these nutrients recommended by Trani et al. (2011), whereas F1 and F2 had higher quantities of K, and F4 and F5 had higher quantities of Ca.

For the lowest salinity $\left(0.5 \mathrm{dS} \mathrm{m}^{-1}\right)$, water from a deep well located at the UFERSA campus was used and its physical and chemical analyses (EMBRAPA, 1997) showed the following characteristics: $\mathrm{pH}=8.30 ; \mathrm{EC}=0.50 \mathrm{dS} \mathrm{m}^{-1} ; \mathrm{Ca}^{2+}=3.10 ; \mathrm{Mg}^{2+}=$ $1.10 ; \mathrm{K}^{+}=0.30 ; \mathrm{Na}^{+}=2.30 ; \mathrm{Cl}^{-}=1.80 ; \mathrm{HCO}_{3}=3.00$ and $\mathrm{CO}_{3}{ }^{2-}=$ $0.20\left(\mathrm{mmol}_{\mathrm{c}} \mathrm{L}^{-1}\right)$.

The other salinity levels $\left(2.0 ; 3.5\right.$ and $\left.5.0 \mathrm{dS} \mathrm{m}^{-1}\right)$ were obtained by adding $\mathrm{NaCl}$ to the water of lowest salinity and adjusting the levels using a benchtop conductivity meter.

Table 1. Quantity of macronutrients applied along the experiment

\begin{tabular}{ccccccc}
\hline \multirow{2}{*}{ Fertigation } & $\mathbf{N}$ & $\mathbf{P}$ & $\mathbf{K}_{\mathbf{2}} \mathbf{0}$ & $\mathbf{C a}$ & $\mathbf{M g}$ & $\mathbf{S}$ \\
\cline { 2 - 7 } $\mathrm{F} 1-\mathrm{K} / \mathrm{Ca}=4.2: 1$ & 10.50 & 2.26 & 47.78 & 11.38 & 7.54 & 6.11 \\
$\mathrm{~F} 2-\mathrm{K} / \mathrm{Ca}=3.5: 1$ & 10.50 & 2.26 & 39.82 & 11.38 & 7.54 & 6.11 \\
$\mathrm{~F} 3-\mathrm{K} / \mathrm{Ca}=2.8: 1$ & 10.50 & 2.26 & 31.85 & 11.38 & 7.54 & 6.11 \\
$\mathrm{~F} 4-\mathrm{K} / \mathrm{Ca}=2.2: 1$ & 10.50 & 2.26 & 31.85 & 14.22 & 7.54 & 6.11 \\
$\mathrm{~F} 5-\mathrm{K} / \mathrm{Ca}=1.8: 1$ & 10.50 & 2.26 & 31.85 & 17.06 & 7.54 & 6.11 \\
\hline
\end{tabular}


Fertigation was applied once a week during the vegetative stage, beginning after transplantation, and lasted 87 days. From the reproductive stage, fertigation was split into two applications per week, and this latter stage lasted 60 days. Nutrient solutions were prepared using the following fertilizers: calcium nitrate, potassium nitrate, monoammonium phosphate, potassium chloride, magnesium sulfate and urea, besides two compounds of micronutrients.

The compounds of micronutrients used were the foliar fertilizers Vegetables and $\mathrm{CaMg}+\mathrm{B}$; the former is composed of $94.90 \mathrm{~g} \mathrm{~L}^{-1}$ of S, $14.60 \mathrm{~g} \mathrm{~L}^{-1}$ of B, $7.30 \mathrm{~g} \mathrm{~L}^{-1}$ of Cu, $116.80 \mathrm{~g} \mathrm{~L}^{-1}$ of $\mathrm{Mn}$ and $43.80 \mathrm{~g} \mathrm{~L}^{-1}$ of $\mathrm{Zn}$, and the latter is composed of $76.80 \mathrm{~g} \mathrm{~L}^{-1}$ of Ca, $25.60 \mathrm{~g} \mathrm{~L}^{-1}$ of $\mathrm{Mg}$ and $12.80 \mathrm{~g} \mathrm{~L}^{-1}$ of $\mathrm{B}$.

Planting was carried out using eggplant seedlings, 'Ciça' hybrid, produced on expanded polystyrene trays with capacity for 128 cells, using coconut fiber as substrate. The trays were kept in a micro-pool supplied with a constant 1-cm-deep film of nutrient solution recommended for the eggplant crop in hydroponic system, until transplantation, when the seedlings had three to four true leaves.

Substrate consisted of soil material classified as Red Yellow Argisol (EMBRAPA, 2013) collected in the 0-0.20 m layer. The physical and chemical attributes of soil (EMBRAPA, 2009) are summerised in Table 2 .

As the pots were filled, each one received $1.0 \mathrm{~L}$ of aged bovine manure and $20 \mathrm{~g}$ of the formulation 10-10-10 (N-P-K) as basal fertilization.

The experiment was conducted in the open and the pots were arranged into four rows spaced by $1.5 \mathrm{~m}$, containing 20 pots each at spacing of $0.5 \mathrm{~m}$ between plants, which was equivalent to a population of 13,333 plants per hectare. In addition, one pot was put at the beginning and another pot at the end of each row, as borders. Each pot had a drainage system composed of crushed stone and a geotextile, to facilitate drainage.

For each type of saline water, an independent irrigation system was adopted, comprising a motor pump, a 500-L tank, 16-mm-diameter hoses and microtubing (spaghetti type)

Cultivation practices, besides irrigation and fertigation, consisted in the removal of buds which appeared before the insertion of the first flower, training and preventive applications of fungicides and insecticides every 15 days.
Table 2. Physical and chemical characteristics of the soil used in the experiment

\begin{tabular}{|c|c|c|c|c|c|c|c|}
\hline \multicolumn{8}{|c|}{ Chemical characteristics } \\
\hline \multirow{2}{*}{$\mathrm{pH}$} & \multirow{2}{*}{$\begin{array}{c}\mathrm{OM} \\
\left(\mathrm{g} \mathrm{kg}^{-1}\right)\end{array}$} & $\mathbf{P}$ & $\mathrm{K}^{+}$ & $\mathrm{Na}^{+}$ & $\mathrm{Ca}^{+2}$ & $\mathrm{Mg}^{+2}$ & $\mathrm{H}^{+}$ \\
\hline & & \multicolumn{3}{|c|}{$\left(\mathrm{mg} \mathrm{dm^{-3 }}\right)$} & \multicolumn{3}{|c|}{$\left(\mathrm{cmol}_{\mathrm{c}} \mathrm{dm}^{-3}\right)$} \\
\hline 6.47 & 10.15 & 10.71 & 176.72 & 35.44 & 2.99 & 1.440 & 1.15 \\
\hline \multicolumn{8}{|c|}{ Physical characteristics } \\
\hline \multicolumn{3}{|c|}{$\begin{array}{c}\text { Granulometric fraction } \\
\qquad\left(\mathrm{g} \mathrm{kg}^{-1}\right)\end{array}$} & \multirow{2}{*}{$\begin{array}{l}\text { Textural } \\
\text { class }\end{array}$} & \multicolumn{2}{|c|}{$\begin{array}{c}\text { Moisture } \\
\left(\mathrm{g} \mathrm{g} \mathrm{g}^{-1}\right)\end{array}$} & \multicolumn{2}{|c|}{$\begin{array}{l}\text { Density } \\
\left(\mathrm{kg} \mathrm{dm}^{3}\right)\end{array}$} \\
\hline Sand & Silt & Clay & & FC & PWP & Ds & Dp \\
\hline 707.2 & 172.2 & 120.6 & SL & 0.15 & 0.06 & 1.53 & 2.68 \\
\hline
\end{tabular}

SL - Sandy Loam; FC - Field capacity for $\psi_{\mathrm{m}}=-10 \mathrm{kPa}$; PWP - Permanent wilting point for $\psi_{\mathrm{m}}=-1500 \mathrm{kPa}$; Ds - Soil apparent or bulk density; DP - Soil particle density

Harvests were carried out every 15 days for 60 days and, in each one of them, the fruits were individually evaluated and the following yield parameters were analyzed: number of fruits per plant (NFR), fruit length (FRL), fruit diameter (FRD), fruit fresh weight (FRFW) and yield (YLD).

The obtained data were subjected to analysis of variance by $\mathrm{F}$ test, with follow-up tests of the factors when there was significant response to their interaction. The results relative to the effects of fertigation were analyzed using means comparison test (Tukey, 0.05 probability level). The effect of salinity was analyzed based on regression analysis. Statistical analyses were carried out using the program Sisvar (Ferreira, 2011).

\section{RESULTS AND Discussion}

Based on the analysis of variance, the interaction between levels of irrigation water salinity and fertigation with different $\mathrm{K} / \mathrm{Ca}$ ratios had significant effect only on the variables number of fruits per plant (NFR) and fruit diameter (FRD) at 0.05 and 0.01 probability levels, respectively. For the individual effects, the different levels of salinity had significant influence on all variables analyzed and, for NFR, fruit length (FRL), fruit fresh weight (FRFW) and yield (YLD), the significance occurred at 0.01 probability level. For the individual effect of different fertigation treatments, only FRD was significantly affected, at 0.01 probability level (Table 3 ).

According to the values of FRD obtained in the different fertigation treatments, it can be observed that fertigation with

Table 3. Summary of the analysis of variance and means comparison test for number of fruits (NFR), fruit length (FRL), fruit diameter (FRD), fruit fresh weight (FRFW) and yield (YLD) of eggplant subjected to salinity and fertigation with different K/Ca ratios

\begin{tabular}{|c|c|c|c|c|c|c|}
\hline \multirow{2}{*}{$\begin{array}{c}\text { Sources } \\
\text { of variation }\end{array}$} & \multirow{2}{*}{ DF } & \multicolumn{5}{|c|}{ Mean squares } \\
\hline & & NFR & FRL & FRD & FRFW & YLD \\
\hline Salinity (S) & 3 & $52.98^{\star \star}$ & $1183.05^{\star \star}$ & $50.61^{\star}$ & $5719.21^{\star \star}$ & $2633021.12^{\star \star}$ \\
\hline Fertigation (F) & 4 & $0.85^{\text {ns }}$ & 111.00 ns & $61.88^{* *}$ & $691.70^{\text {ns }}$ & $86336.95^{\text {ns }}$ \\
\hline$S \times F$ & 12 & $6.24^{\star}$ & $160.62^{\mathrm{ns}}$ & $41.65^{\star \star}$ & $930.83^{\text {ns }}$ & $104425.49^{\text {ns }}$ \\
\hline Block & 3 & $0.14^{\mathrm{ns}}$ & $100.01^{\text {ns }}$ & $10.43^{\text {ns }}$ & $1019.34^{\text {ns }}$ & $86113.33^{\text {ns }}$ \\
\hline Residual & 57 & 2.53 & 96.17 & 15.60 & 588.35 & 76699.73 \\
\hline CV (\%) & & 22.25 & 9.73 & 6.53 & 16.15 & 25.52 \\
\hline $\begin{array}{c}\text { Test of means } \\
\text { fertigation }\end{array}$ & & (unit plant ${ }^{-1}$ ) & \multicolumn{2}{|c|}{$(\mathrm{mm})$} & ( $\mathrm{g}$ fruit $^{-1}$ ) & (g plant ${ }^{-1}$ ) \\
\hline $\mathrm{F} 1-\mathrm{K} / \mathrm{Ca}=4.2: 1$ & & $7.12 \mathrm{a}^{\#}$ & 99.74 a & $63.59 \mathrm{a}$ & $158.11 \mathrm{a}$ & $1150.82 \mathrm{a}$ \\
\hline $\mathrm{F} 2-\mathrm{K} / \mathrm{Ca}=3.5: 1$ & & $7.50 \mathrm{a}$ & $104.71 \mathrm{a}$ & $61.31 \mathrm{ab}$ & $155.06 \mathrm{a}$ & $1170.99 \mathrm{a}$ \\
\hline $\mathrm{F} 3-\mathrm{K} / \mathrm{Ca}=2.8: 1$ & & $7.20 \mathrm{a}$ & $100.69 \mathrm{a}$ & $58.99 b$ & $148.24 \mathrm{a}$ & $1063.29 \mathrm{a}$ \\
\hline $\mathrm{F} 4-\mathrm{K} / \mathrm{Ca}=2.2: 1$ & & $6.94 \mathrm{a}$ & $97.48 \mathrm{a}$ & $59.40 \mathrm{~b}$ & $141.28 \mathrm{a}$ & $997.22 \mathrm{a}$ \\
\hline $\mathrm{F} 5-\mathrm{K} / \mathrm{Ca}=1.8: 1$ & & $6.94 \mathrm{a}$ & $101.35 \mathrm{a}$ & $59.18 \mathrm{~b}$ & $148.37 \mathrm{a}$ & $1043.99 \mathrm{a}$ \\
\hline
\end{tabular}

${ }_{\mathrm{ns}},{ }^{*}{ }^{\star *}$ Not significant, significant at 0.05 and 0.01 probability levels, respectively. ${ }^{*}$ Means followed by the same letter in the column do not differ by Tukey test at 0.05 probability level 
K-rich solutions (F1 and F2) led to the greatest diameters in eggplant fruits (Table 3).

Regardless of the $\mathrm{K} / \mathrm{Ca}$ ratio adopted in fertigation, the variables FRL (Figure 2A), FRFW (Figure 2B) and YLD (Figure 2C) showed linear and negative responses, and decreased progressively with the increase in the electrical conductivity of the water used in irrigation.

Highest values of FRL (109.4 mm), FRFW (107.5 $\mathrm{g} \mathrm{fruit}^{-1}$ ) and YLD (1502.0 g plant $^{-1}$ ) occurred when plants were subjected to the lowest salinity level and progressively decreased with the use of saline water. The reductions were equal to $3.83 \mathrm{~mm}$ in FRL (Figure 2A), $2.87 \mathrm{~g} \mathrm{fruit}^{-1}$ in FRFW (Figure 2B) and 185.2 g plant $^{-1}$ in YLD (Figure 2C), per unit increase in irrigation water electrical conductivity, resulting in total losses of 15.72, 12.04 and 55.48\% for FRL, FRFW and YLD, respectively (Figure 2).

These results confirm that eggplant is a crop sensitive to salinity (Ünlükara et al., 2010) and agree with the results reported by other authors (Silva et al., 2013, Moura \& Carvalho, 2014; Oliveira et al., 2014; Lima et al., 2015).

A.

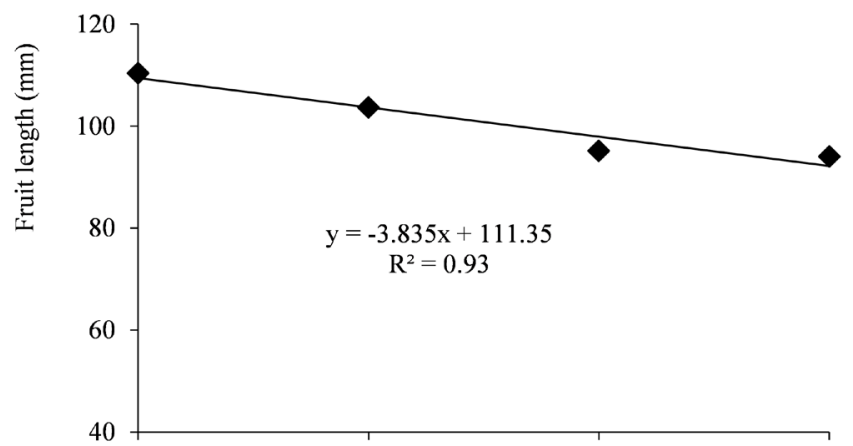

B.

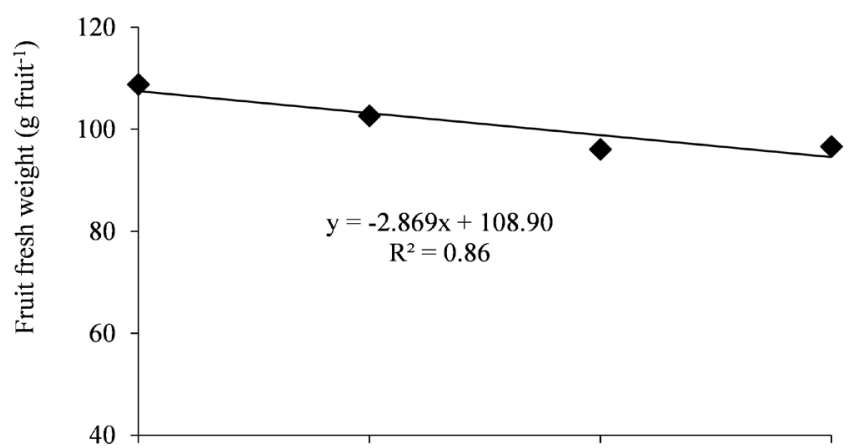

C.

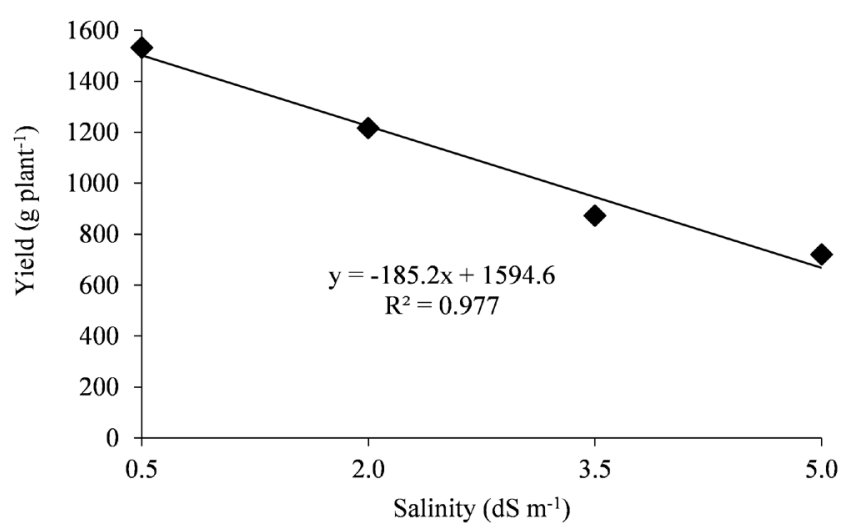

Figure 2. Fruit length (A), fruit fresh weight $(B)$ and yield (C) of eggplant as a function of irrigation water salinity
According to the effect of salinity on FRD, significant effect was only caused by the fertigation treatments F1 and F4, and this variable showed quadratic responses. In these fertigation treatments, fruit diameter decreased as salinity increased to 2.4 and $3.3 \mathrm{dS} \mathrm{m}^{-1}$, with 59.1 and $55.6 \mathrm{~mm}$ for F1 and F4, respectively, and increased from these points on. For the other fertigation treatments, there was no effect of salinity on FRD, and mean values of $61.31,58.99$ and $59.17 \mathrm{~mm}$ were found in F2, F3 and F5, respectively (Figure 3A).

Other authors, working with increasing levels of salinity in the eggplant crop, have also observed reductions in FRD as irrigation water electrical conductivity increased (Ghaemi \& Rafiee, 2016; Mahjoor et al., 2016), and the values varied between 66 and $27 \mathrm{~mm}$ at the lowest and highest levels of salinity, respectively.

The reason for this decrease in production variables, such as fruit diameter, is that salinity has considerable effects on plant osmotic potential, reducing water absorption and, consequently, the water flux to the fruits (Gül \& Sevgican, 1992).

For NFR, the fertigation treatments F1, F2, F3 and F5 caused negative linear response, and the reductions per unit increase in irrigation water electrical conductivity were 0.77 , $0.63,1.35$ and 0.88 fruits plant $^{-1}$, resulting in total losses of $39.14,31.72,59.39$ and $44.34 \%$, respectively. The fertigation treatment F4 led to higher tolerance for this variable, causing a quadratic response, in which the highest NFR was obtained at salinity of $2.2 \mathrm{dS} \mathrm{m}^{-1}$ (8.4 fruits plant ${ }^{-1}$ ), an increase of $18.43 \%$ compared with the NFR obtained using water with the lowest

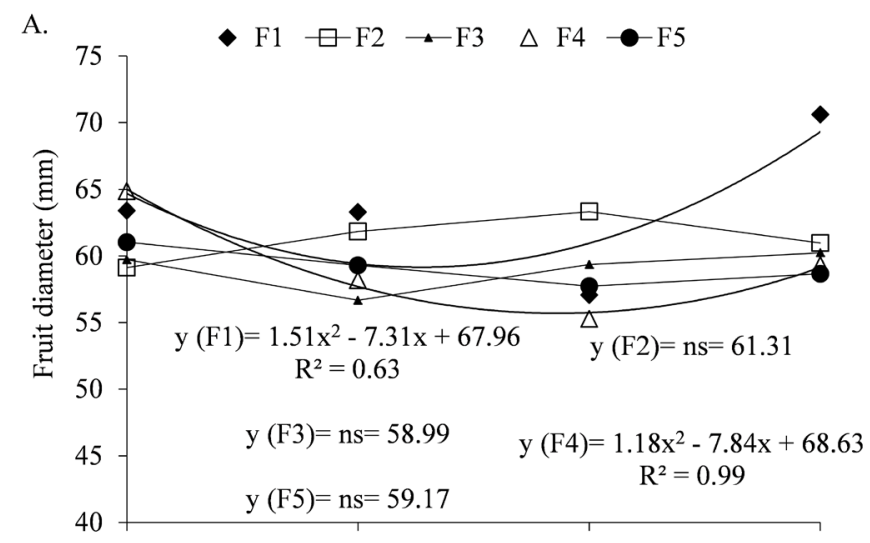

B.

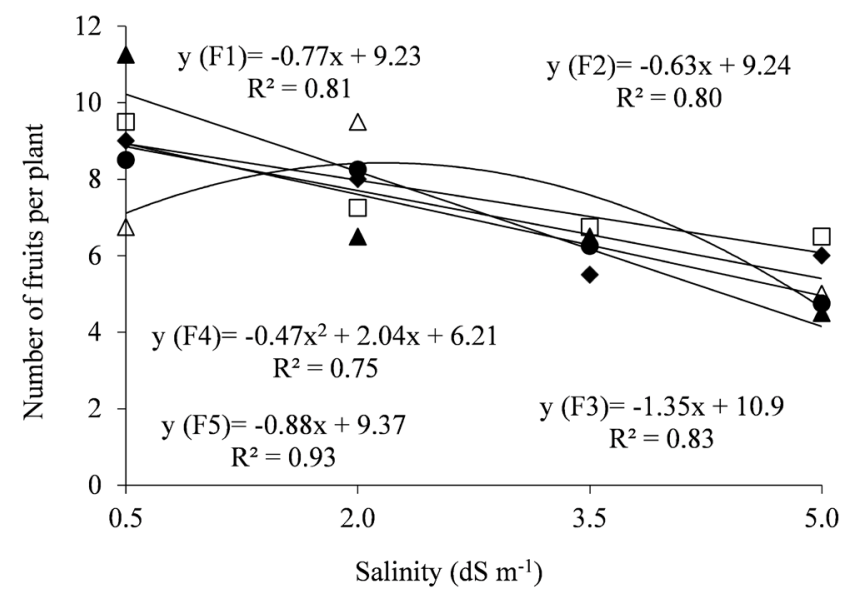

Figure 3. Fruit diameter (A) and number of fruits (B) of eggplant as a function of the combination between irrigation water salinity and fertigation management 
salinity level (7.1 fruits plant $\left.{ }^{-1}\right)$. In addition, NFR decreased at the highest levels of salinity (Figure 3B).

The reduction in the number of fruits occurred mainly because the increase in irrigation water salinity affected plants physiologically, hindering the fertility of the flowers (Ferreira Neto et al., 2007). Similar results have been observed by Oliveira et al. (2014), working with eggplant, and other authors in other vegetables, such as bell pepper (Leonardo et al., 2008) and tomato (Gomes et al., 2011; Guedes et al., 2015).

The reduction in production variables is probably caused by the increase in salinity, since it causes alterations in the osmotic potential, reducing the consumption of water and nutrients, thus decreasing fruit setting rate and consequently fruit production (Oliveira et al., 2014).

In general, the present study found low interaction between $\mathrm{K} / \mathrm{Ca}$ ratios and the effect of salinity on eggplant yield. Tuna et al. (2007) and Blanco et al. (2007), evaluating the tolerance of tomato to salinity at different levels of $\mathrm{Ca}$ and combinations of $\mathrm{N}$ and $\mathrm{K}$ doses in the nutrient solution, respectively, observed that these nutrients did not mitigate the effects of salinity on some production and morphological characteristics of the crop.

\section{Conclusions}

1. The variables fruit length, number of fruits, yield and fruit fresh weight were reduced by the increase in irrigation water salinity, regardless of the type of fertigation used.

2. The K/Ca ratios studied did not interfere with the effect of salinity on eggplant fruit yield.

\section{ACKNowledgements}

The authors thank the National Council for Scientific and Technological Development (CNPq) for financially supporting the project $(\mathrm{CNPq} /$ Universal Call 2013, process $n^{\circ} 474778 / 2013-4$ ).

\section{Literature Cited}

Albino-Garduño, R.; Zavaleta-Mancera, H. A.; Ruiz-Posadas, L. M.; Sandoval-Villa, M.; Castillo-Morales, A. Response of gerbera to calcium in hydroponics. Journal of Plant Nutrition, v.31, p.91-101, 2008. https://doi.org/10.1080/01904160701741958

Blanco, F. F.; Folegatti, M. V. Doses de N e K no tomateiro sob estresse salino: III. Produção e qualidade dos frutos. Revista Brasileira de Engenharia Agrícola e Ambiental, v.12, p.34-40, 2007. http:// dx.doi.org/10.1590/S1415-43662008000200003.

Bosco, M. R. de O.; Oliveira, A. B. de; Hernandez, F. F. F.; Lacerda, C. F. de. Influência do estresse salino na composição mineral da berinjela. Revista Ciência Agronômica, v.40, p.157-164, 2009.

Bsoul, E. Y.; Jaradat, S.; Al-Kofahi, S.; Al-Hammouri, A.; Alkhatib, R. Growth, water relation and physiological responses of three eggplant cultivars under different salinity levels. Jordan Journal of Biological Sciences, v.9, p.123-130, 2016.

Carmo Filho, F.; Oliveira, O. F. Mossoró: Um município do semi-árido nordestino, caracterização climática e aspecto florístico. Mossoró: ESAM, 1995. 62p. Coleção Mossoroense, Série B
Costa, D. M. A. Impactos da irrigação na variabilidade espacial e temporal da salinidade de um solo aluvial no semi-árido potiguar. Holos, v.24, p.62-71, 2008. https://doi.org/10.15628/ holos.2008.169

EMBRAPA - Empresa Brasileira de Pesquisa Agropecuária. Manual de métodos de análises de solo. 2.ed. Rio de Janeiro: Embrapa Solos, 1997. 212p.

EMBRAPA - Empresa Brasileira de Pesquisa Agropecuária. Manual de análises químicas de solos, plantas e fertilizantes. 2.ed. Brasília: Embrapa Informação Tecnológica, 2009. 627p.

EMBRAPA - Empresa Brasileira de Pesquisa Agropecuária. Sistema brasileiro de classificação de solos. 3.ed. Rio de Janeiro: Embrapa Solos, 2013. 353p.

FAO - Food and Agriculture Organization of the United Nations. Disponível em: <http://faostat.fao.org/site/567/default. aspx\#ancor $>$. Acesso em: Ago. 2015.

Ferreira, D. F. Sisvar: A computer statistical analysis system. Ciência e Agrotecnologia, v.35, p.1039-1042, 2011. http://dx.doi. org/10.1590/S1413-70542011000600001

Ferreira Neto, M.; Gheyi, H. R.; Fernandes, P. D.; Holanda, J. S. de; Blanco, F. F. Emissão foliar, relações iônicas e produção do coqueiro irrigado com água salina. Ciência Rural, v.37, p.16751681, 2007. http://dx.doi.org/10.1590/S0103-84782007000600026.

Ghaemi, A. A.; Rafiee, M. R. Evapotranspiration and yield of eggplant under salinity and water deficit: A comparison between greenhouse and outdoor cultivation. Modern Applied Science, v.10, p.8-18, 2016. https://doi.org/10.5539/mas.v10n11p8

Gomes, J. W. da S.; Dias, N. da S.; Oliveira, A. M. de; Blanco, F. F.; Sousa Neto, O. N. de. Crescimento e produção de tomate cereja em sistema hidropônico com rejeito de dessalinização. Revista Ciência Agronômica, v.42, p.850-856, 2011.

Guedes, R. A. A.; Oliveira, F. A. de; Alves, R. de C.; Medeiros, A. S. de; Gomes, L. P.; Costa, L. P. Estratégias de irrigação com água salina no tomateiro cereja em ambiente protegido. Revista Brasileira de Engenharia Agrícola e Ambiental, v.19, p.913-919, 2015. http:// dx.doi.org/10.1590/1807-1929/agriambi.v19n10p913-919

Gül, A.; Sevgican, A. Effect of growing media on glasshouse tomato yield and quality. Acta Horticulturae, v.303, p.145-150, 1992.

Leonardo, M.; Broetto, F.; Villas-Bôas, R. L.; Marchese, J. A.; Tonin, F. B.; Regina, M. Estado nutricional e componentes da produção de plantas de pimentão conduzidas em sistema de fertirrigação durante indução de estresse salino em cultivo protegido. Bragantia, v.67, p.883-889, 2008. http://dx.doi.org/10.1590/S000687052008000400010

Lima, L. A.; Oliveira, F. A.; Alves, R. C.; Linhares, P. S. F.; Medeiros, A. M. A.; Bezerra, F. M. S. Tolerância da berinjela à salinidade da água de irrigação. Revista Agro@ambiente On-line, v.9, p.27-34, 2015.

Mahjoor, F.; Ghaemi, A. A.; Golabi, M. H. Interaction effects of water salinity and hydroponic growth medium on eggplant yield, wateruse efficiency and evapotranspiration. International Soil and Water Conservation Research, v.4, p.99-107, 2016. https://doi. org/10.1016/j.iswcr.2016.04.001

Malavolta, E. Manual de nutrição mineral de plantas. São Paulo: Agronômica Ceres, 2006. 638p.

Medeiros, J. F.; Lisboa, R. A.; Oliveira, M.; Silva Junior, M. J.; Alves, L. P. Caracterização das águas subterrâneas usadas para irrigação na área produtora de melão da Chapada do Apodi. Revista Brasileira de Engenharia Agrícola e Ambiental, v.7, p.46-472, 2003. http:// dx.doi.org/10.1590/S1415-43662003000300010 
Moura, D. C. M.; Carvalho, J. A. Efeitos de diferentes lâminas e teores de sais na água de irrigação sobre o desenvolvimento e produção da berinjela. Irriga, v.19, p.35-45, 2014. http://dx.doi. org/10.15809/irriga.2014v19n1p35

Oliveira, F. de A. de; Medeiros, J. F. de; Alves, R. de C.; Linhares, P. S. F.; Medeiros, A. M. de A.; Oliveira, M. K. T. Interação entre salinidade da água de irrigação e adubação nitrogenada na cultura da berinjela. Revista Brasileira de Engenharia Agrícola e Ambiental, v.18, p.480-486, 2014. http://dx.doi.org/10.1590/ S1415-43662014000500003

Rubio, J. S.; García-Sánchez, F.; Rubio, F.; Martínez, V. Yield, blossomend rot incidence, and fruit quality in pepper plants under moderate salinity are affected by $\mathrm{K}^{+}$and $\mathrm{Ca}^{2+}$ fertilization. Scientia Horticulturae, v.119, p.79-97, 2009. https://doi.org/10.1016/j. scienta.2008.07.009

Silva, E. M. da; Lima, C. J. G. de S.; Duarte, S. N.; Barbosa, F. da S.; Maschio, R. Níveis de salinidade e manejo da fertirrigação sobre características da berinjela cultivada em ambiente protegido. Revista Ciência Agronômica, v.44, p.150-158, 2013.
Tammam, A. A. E.; Alhamd, M. F. A.; Hemeda, M. M. Study of salt tolerance in wheat (Triticum aestium L.) cultivar Banysoif 1. Australian Journal of Crop Science, v.1, p.115-125, 2008.

Trani, P. E.; Tiveli, S. W.; Carrijo, O. A. Fertirrigação em hortaliças. 2.ed. rev. atual. Campinas: Instituto Agronômico de Campinas, 2011. 51p. Série Tecnologia APTA - Boletim Técnico, 196

Tuna, A. L.; Kaya, C.; Ashraf, M.; Altunlu, H.; Yokas, I.; Yagmur, B. The effects of calcium sulphate on growth, membrane stability and nutrient uptake of tomato plants grown under salt stress. Environmental and Experimental Botany, v.59, p.173-178, 2007. https://doi.org/10.1016/j.envexpbot.2005.12.007

Tzortzakis, N. G. Potassium and calcium enrichment alleviate salinityinduced stress in hydroponically grown endives. HortScience. v.37, p.155-162, 2010.

Ünlükara, A.; Kurunç, A.; Kesmez, G. D.; Yurtseven, E.; Suarez, D. L. Effects of salinity on eggplant (Solanum Melongena L.) growth and evapotranspiration. Journal of Irrigation and Drainage, v.59, p.203-214, 2010. https://doi.org/10.1002/ird.453 